\title{
PROFESSIONAL ENGINEERS IN BRITAIN
}

T HAT engineering can be practised as a profession has been recognized in Great Britain for well over a century. The registration of professional engineers, a practice which has become established in a good many other parts of the world, has not found favour in Great Britain, and the standards of the profession. have been built up and are maintained by the professional engineering institutions, notably the Institutions of Civil Engineers, of Mechanical Engineers and of Electrical Engineers.

There has been since the Second World War in all the engineering institutions a good deal of reviewing of academic standards, of requirements for practical training, and indeed in quite a fundamental sense of the meaning to be ascribed to the term 'professional engineer'. It is not therefore surprising that Sir Willis Jackson should choose as the theme of his presidential address to the Institution of Electrical Engineers, delivered on October 9, "The Making of Professional Engineers".

Education, training and the social and economic setting in which engineers pursue their vocation come under review in a balanced assessment and penetrat. ing analysis of what might be termed the production and utilization of professional engineers in Great Britain. That the sustained effort which has been made in recent years to attract an increased proportion of the more able young people to take up careers in science or technology is beginning to bear fruit, is clearly evidenced by data given in the address. The numbers of schoolboys and schoolgirls passing the Advanced Level General Certificate of Education examination in the subjects of physics, chemistry and mathematics increased between 1953 and 1958 by some 59 per cent, 43 per cent, and 65 per cent, respectively, the corresponding increase in school population over fifteen years of age in the period being some 26 per cent. While radio, television, the national Press and official publications have all shared in this effort, there is no doubt that a major contribution has been made by industry by fostering a closer contact between schoolmasters and the staff of industrial organizations. In addition, the teaching of experimental science in the independent schools has been stimulated and greatly assisted by the Industrial Fund for the Advancement of Scientific Education which was established in 1955 .

Gratifying as this increase in numbers is, there is, on the other hand, little cause for satisfaction as to progress in the attempt to broaden the sixth-form school curriculum. The comment is made that a factor which militates against any broadening of the curriculum is the high standard of specialist knowledge required by the universities for entry to undergraduate courses. While this is in large measure true, it must be realized that there are in fact two related factors. The first is the admittedly high standard of knowledge required and the second is the extreme pressure of applications for the available places in the universities. University places are highly competitive and the better the pass the better the chance of acceptance. It may well be that sixth-form work in schools is bedevilled more by the need to limit objectives, in the hope of achioving a high place in the examination, than by the intrinsic requirements of the examination syllabuses themselves.

Another development in schools which Sir Willis notes with disapprobation is the introduction of engineering subjects into the sixth-form curriculum. These, he suggests, are possibly introduced with the aim of stimulating interest in engineering as a career and providing an incentive to serious study. It would, however, be through a misconception of the educational needs of the professional engineer, if grammar schools were to encourage boys with little aptitude for mathematics and the basic sciences to continue at school up to the age of eighteen to study technical subjects. "The profession of engineering is," he asserts, "no haven for the scientific weakling." That is a dictum which cannot be too often reiterated to every schoolmaster.

Science teaching in schools is, however, determined by the availability of suitably qualified teachers, and the continuing shortage of teachers of science dominates all other considerations relating to the development of pure and applied science. Sir Willis Jackson states the facts with a simplicity which signalizes the urgency of the situation. In 1965 the school population of seventeen-year-olds will reach its peak of twice the 1959 numbers. In 1958 , there were, in maintained secondary schools, some 8,900 teachers of mathematics, physics or chemistry, but more than 800 posts in these subjects were either vacant or unsatisfactorily filled. While there is a small but definite improvement in the rate of recruitment to school teaching among science graduates, this will be completely outstripped by the rate of increase of the corresponding school population, altogether apart from the leeway which still requires to be made up. Allowing that there is considerable reserve of capacity resulting from the small numbers in many sixth-form classes, it is none the less evident that the shortage must become acute. Referring to this problem, Sir Willis comments that salary is by no means the only consideration that affects the willingness of science graduates to enter the teaching profession. Teaching facilities, amenities and general conditions of employment are also important factors. It is worth while in this connexion to note that the shortage of teachers in technical colleges is less acute than in schools. Salary scales are rather better, but equally or even more importantly, the technical college teacher has greater freedom from incidental duties, has first-class laboratory facilities and he is encouraged to pursue research. In individual in. stances pupils have transferred from schools having inadequate science teaching to neighbouring technical colleges where fully satisfactory facilities have been available. While such transfers of pupils on any substantial scale would subvert for the time being the policy of building up the sixth-form science teaching in schools, their utilization as a temporary emergency measure should not be overlooked. 
The number of undergraduate students of science and technology in the universities of Great Britain has increased by a factor of nearly three since 1938-39 and now constitutes about 38 per cent of the total university student population of almost 100,000 . For the most part these students pursue courses of three years duration. Of these undergraduates, about 40 per cent study engineering or some branch of applied science; but it must be remembered that an appreciable proportion of graduates in pure science, particularly in physics and chemistry, becomo technologists. The Institution of Electrical Engineers accepts into its membership an increasing number of such physicists.

Sir Willis Jackson takes note of the pressure to increase the length of the undergraduate course, a pressure resulting from the remarkable expansion of the field of knowledge and from recognition of the undesirable degree of specialization existing both in school and undergraduate courses. He does not, however, concede the point that if an extension were practicable it would necessarily be desirable to make it. He considers that for the majority of students of technology three years in the university constitutes a long enough preparation for active participation in the affairs of life outside. In his opinion it is of greater importance to examine afresh the objectives and content of university courses in technology in the light of the new situation, in which a substantial contribution to the teaching of technology at university-level is being made by the colleges of advanced technology. This is indeed a matter of first importance. The universities and the colleges of advanced technology are partners in the education of that section of the youth of Great Britain destined to become the professional engineers and applied scientists.

The new diploma in technology has been conceived and developed with the underlying assumption that there is an approach to the study of applied science which has more emphasis on application than is appropriate to universities, but which can still constitute an academic discipline of university rank. It is believed that by virtue of the integration of studies with industrial experience, the student will be better able to appreciate aspects of technology and to approach, with greater understanding, subjects related to the organization of industry. This is the factor which gives its distinctive quality to the diploma in technology. The validity of this assumption is being put to the proof in courses which are now running in the eight colleges of advanced technology and in the regional colleges which have so far been established. There is encouraging evidence that these courses are justifying the hopes of their designers. At the same time, it is clear that a conscious and sustained effort will be required to ensure that courses for the diploma in technology and courses in universities supplement one another and that, by fostering and emphasizing their distinctive qualities, the two combine to augment the national total of applied scientists. Sir Willis implies that both the universities and the colleges of tochnology should give serious thought to identifying what are to be the essential distinctive qualities of their courses so that the danger may be avoided of both types of institution offering courses which academically are scarcely distinguishable.

Postgraduate study and research are subjects also very relevant to the making of professional engineers.
Research in one form or another is the vital force of acadernic life, whether the academy be a university or a college of technology. The spirit of inquiry which should characterize the outlook and inspire the teaching of the staffs of universities and colloges requires for its nurture not only a favourable intellectual climate but also the physical resources for its growth. The pattern of the research schools in the universities is essentially in the classical tradition in the sense that the master gathers about him a group of the most able young scholars who, on one hand, draw inspiration from the master and on the other furnish him with the stimulus of their fresh intellects and the challenge of their problems. Research in tho physical sciences requires facilities and services of increasing magnitude and complexity, and when the sciences are applied sciences, the situation becomes vastly more complicated by the interrelation between practice and science. Here unquestionably the stimulus of achievement in application can match and even surpass that of intellectual curiosity.

It is, in the opinion of Sir Willis Jackson, quite unrealistic to suppose that the teaching of technology at its highest level can be carried out wholly or largely by men who occupy full-time teaching posts, unless these men return to industry or a similar environment, at appropriate intervals. He commends the practice, long established in other countries, by which, for limited periods, carefully selected experts from industry or government establishments are given academic status and contribute to the advanced specialist teaching of technology. Drawing a parallel with the position of medical clinicians, who carry full academic standing in the universities, he goes on to suggest that the separation of establishments of the Department of Scientific and Industrial Research from the domain of technological teaching constitutes a serious national handicap. It would, he considers, be a useful first step if these research establishments and some of the research associations could be accepted as recognized institutions of universities in the sense that selected members of their staffs could be fully recognized as teaching members of appropriate faculties.

That the highest lovel of knowledge of the specialized applications of science to technology resides in industrial and government researeh establishments and design departments is undeniable. It is, however, equally true that there is a network of informal association between the staffs of universities and colleges, and those of industrial organizations and government establishments. The extent and importance of this must not be under-estimated. Exchange of information, participation in seminars, membership of research committees and the provision of specialist lecturers-all these feature in an informal and cordial co-operation from which the greatest benefit is derived. It is a widening of this association and its organization on a more formal basis which Sir Willis Jackson advocates. The practice in the technical universities of the Continent of Europe of appointing as professors distinguished engineers and scientists in industry who then divide their time and attention between their academic and their industrial responsibilities possesses the great merit of bringing current industrial problems directly to the notice of students. The Continental system, however, has its drawbacks. Faculties are much less closely knit than in Great Britain, and co-ordination of teaching is, by com- 


\section{No. 4705 January $2,1960 \quad$ N A T U R E}

parison, relatively slight. Not infrequently academic visitors from the Continent remark with appreciation upon the unity and coherence not only of faculties but also of complete universities in Great Britain. If a university department were to lean unduly upon the support of a group of experts from outside, it would be in danger of weakening that intellectual integrity and coherence which are its priceless possessions. Undoubtedly the strengthening of the link between technological teaching and industry is of major importance. The success of whatever methods are adopted to that end will be gauged by the growing intrinsic strength of university and college departments.

It is only relatively recently that universities and colleges have made regular and systematic provision for postgraduate study. Sir Willis stresses that the need for postgraduate courses will grow, and that participation in providing them must be recognized and accepted as an increasing necessity. Referring to postgraduate study in university departments of engineering, he subscribes to the view that a period of industrial training is an essential pre-requisite to the choice of a field of advanced work and to effective study in it. That industry has made only a very limited response to the offers of courses of post. graduate study which have so far been made by universities is, in Sir Willis's opinion, due in part to the shortage of graduates at a time of expanding industrial activity and in part to a measure of inflexibility in universities themselves. Courses of shorter duration than a full university session would, he believes, have been more attractive.

Sir Willis does not, however, refer to a feature of postgraduate study which is of considerable significance, namely, that there are in fact two fairly well differentiated types of postgraduate course which might be described as specialist and fundamental. The specialist course deals with a branch of technology in which advanced methods of analysis and design have been formulated, the significance of which will be best appreciated by someone already familiar with the practice of the subject. The fundamental course, on the other hand, simply represents an extension of the undergraduate course. The potential research engineer who has completed the normal undergraduate course in engineering starts his industrial career with a severe handicap in that he possesses only the most superficial knowledge of modern physics. In all probability he also has but little familiarity with the methods now available for tackling intract. able problems with the aid of computers. These are examples of fundamental matters, an appreciation of which is not critically dependent upon industrial experience; equally importantly, they constitute rigorous studies to which the mind is unlikely ever to be better attuned than at the end of the undergraduate course. There are cogent arguments in favour of accepting for such fundamental courses, immediately after graduation, those honours graduates who show real aptitude for theoretical studies.

In the provision of postgraduate courses on a parttime basis, the major technical colleges of Great Britain have a noteworthy record. The new colleges of advanced technology are building up rapidly their activities in the postgraduate field, and their close association with industry places them in a very advantageous position for doing so. Research projects undertaken with the view of qualifying for the new higher award of the National Council for Technological Awards will normally be carried out mainly in industry but in close association with the teachers of one of the colleges of advanced technology. It is a happy augury for the future co-operation of universities and colleges of advanced technology that the postgraduate award of the National Council, the membership of the College of Technologists, will be available to suitably qualified university graduates and, equally, the universities will accept suitable holders of the diploma in technology as postgraduate students pursuing courses of postgraduate study or research leading to higher degrees. There is here an opportunity for forming a most fruitful association between the two types of institution. Just as at the undergraduate-level there will be a broad overlap in the courses themselves and in the qualities and the abilities of the men who pursue them, so in the postgraduate field will there be many courses of study and many research projects which could be pursued equally well in either type of institution. None the less, if the theory of the diploma in technology is well founded, there will be a general bias towards more applied problems in the colleges of technology and towards more fundamental problems in the universities. Common seminars, joint discussions and the occasional sharing of experimental facilities, will disclose a great community of interest and serve to engender that mutual respect which is the basis of true friendship.

The professional engineer requires practical training in addition to his academic qualifications, and Sir Willis Jackson devotes a good deal of attention to this subject. The fact is that the practical training facilities of Britain are already inadequate in scale, and Sir Willis describes the shortage of these facilities as the Achilles heel of our national plans for the further development of technical and technological education. The large manufacturing organizations have welldeveloped schemes of graduate apprenticeship, but the number of young graduates requiring training is already in excess of the number which these companies can handle satisfactorily. Sir Willis advocates the more active development of group training schemes in which smaller and more specialized firms co-operate in a scheme in which their limited individual resources are combined to provide a balanced training.

Difficulty in obtaining satisfactory practical training is a matter which affects very directly the Dip.Tech.(Eng.), for the qualification certifies not only that its possessor has attained the requisite academic standard but also that he has satisfactorily completed the required period of practical training. The problem of ensuring that this training has been satisfactorily carried out and that a proper balance has been maintained among its constituent parts is not easy of solution. It does, however, demand the closest attention, for a reliable method of assessment of practical training will ensure for the diploma in technology, in its training aspect, the standing and recognition which it merits.

Dealing with the utilization of our scientific man. power, Sir Willis considers that the efficient use of professional engineers and scientists is severely handicapped by failure to tackle effectively the education and training of the craftsmen and technicians by whom they should be supported. In addition to that, there is, he believes, much duplication of effort in research and design departments within the large 
organizations and between manufacturing industry and the research associations. This dissipation of effort reduces the resources which could be mobilized to launch a powerful attack on a new field.

Shortage of university places and limitations in the availability of practical training facilities may at first sight appear a fairly domestic matter. The fact is, however, that these limitations react very seriously on our ability to provide education and training for potential engineers and scientists from the Commonwealth and particularly from the underdeveloped countries. As a contribution to international co-operation and as a tangible expression of good will, a substantial increase in our education and training facilities, provided specifically for overseas students of technology, would do much to strengthen our national self-respect and would redound in more senses than one to our credit.

\title{
SCIENTIFIC CENTENARIES IN 1960
}

\author{
BY JOAN M. EYLES
}

$T$ HE contributions to science made by royal persons lie more in the realm of patronage than in the performance of scientific work. One recalls the association of Charles II with the Royal Society, Louis XIV with the Royal Academy of Sciences in Paris and Frederick I with the Berlin Academy. Nevertheless, there have beon some notable exceptions. The two Medici brothers, Grand Duke Ferdinand II and Leopold, were deeply interested in science, had a laboratory, and were responsible for the formation of the Academia del Cimento. Both Prince Rupert, cousin of Charles II, and Philip, Duke of Orleans, brother of Louis XIV, devoted much of their time to scientific study; while in Scotland James IV took part in alchemical operations.

This year, in Lisbon, an International Congress of the History of Discoveries, to be held under the auspices of the Portuguese Government, will commemorate the five hundredth anniversary of the death of another royal scientist, Prince Henry the Navigator. Prince Henry, the third surviving son of King John I of Portugal, was half English, for his mother was a daughter of John of Gaunt, the fourth son of Edward III. Prince Henry devoted his lifo to organizing voyages of exploration, both along the west coast of Africa and to the different groups of islands in the Atlantic. He resided for more than twenty years at Sagres, close to Cape St. Vincent, whence he could look out over the Atlantic. Here he briefed his captains and studied their reports. He employed skilled mathematicians and astronomers to instruct his navigators and to prepare charts, so that under his supervision Sagres became a centre of goographical research. The proceedings of the Congress should throw new light on this important era of discovery and colonization.

Another outstanding man with a gift for organization, this time an English physician, was Thomas Linacro (1460-1524). His name will always be associated with the foundation, in 1518, of the College of Physicians of London, of which he was the first president, meetings being held at his house. $\mathrm{He}$ also endowed three lectureships in medicine, two at Oxford and one at Cambridge. Linacre, who was physician to Henry VIII, and to many other great men of the time, had studied medicine at Padua. His only medical writings were translations of a number of works by Galen; but he was also the author of a Latin syntax and two elementary grammar's, and he had a high reputation as a Greek and Latin scholar.
The sixteenth century saw the beginnings of British attempts at colonization of the North American coast. In 1585 a large party was sent by Sir Walter Raleigh to form the first colony. With them went Thomas Hariot, the man of science chosen by Raleigh to make a survey of the new land, and to report on the mineral resources, as well as plant and animal life. Hariot, born in 1560, and already distinguished as a mathematician, made a report, published in 1588, entitled "A Briefe and True Report of the New Found Land of Virginia", which is now a very rare book. Afterwards, he resumed the study of mathematics, and made important contributions to the theory of equations; and he was the first to use the two signs of inequality. His book on algebra, "Artis Analyticae Praxis", was not published until 1631, ten years after his death.

Contemporary with Hariot was the Swiss botanist Caspar (or Gaspard) Bauhin, born at Basle in 1560 . His principal work, "Pinax Theatri Botanici", in which he described some six thousand species, appeared in 1623, a year before his death. Bauhin did invaluable work in disentangling the many botanical synonyms in use at that time and also made one of the first attempts at systematic classification. $\mathrm{He}_{\theta}$ abandoned the method of describing plants in alphabetical order of name, and used instead a binomial nomenclature, in which he anticipated Linnaeus.

This year is the tercentenary of the death of the mathematician who invented the slide rule, and also introduced those familiar signs, $x$ for multiplication and : : for ratio. This was William Oughtred, born at Eton, where his father was a master in the College. He was elected to a fellowship in King's College, Cambridge, at the age of twenty. He was devoted to mathematical studies, and the time spent on thern, he said, "I redeemed night by night from my natural sleep, defrauding my body, and inuring it to watching, cold and labour, while others took their rest". Most of his life was spent as rector of Albury, in Surrey, where many students of mathematics, including Seth Ward, Wallis and Wren, visited him for instruction and discussion. Oughtred was the author of a highly esteemed text-book of arithmetic and algebra, "Clavis Mathomaticae", which went into a numbor of editions, and was later translated into English with a preface by Halley.

Two men, both of whom became professors of medicine at the nowly founded University of Halle, and who shared an interest in chemistry, wore born in 1660. The senior of the two was Friedrich Hoff- 